\title{
Relationship of glycogen and lactate concentrations as a pork quality indicator
}

\author{
A. Zybert ${ }^{1}$, K. Tarczyński ${ }^{1 \#}$, H. Sieczkowska ${ }^{1}$, E. Krzęcio-Nieczyporuk ${ }^{2}$ \& K. Antosik ${ }^{2}$ \\ ${ }^{1}$ Faculty of Agrobioengineering and Animal Husbandry, and ${ }^{2}$ Faculty of Medical and Health Sciences \\ Siedlce University of Natural Sciences and Humanities, 08-110 Siedlce, Prusa 14 Street, Poland
}

(Received 14 August 2019; Accepted 22 November 2019; First published online 16 February 2020)

Copyright resides with the authors in terms of the Creative Commons Attribution 4.0 South African Licence.

See: http://creativecommons.org/licenses/by/4.0/za

Condition of use: The user may copy, distribute, transmit and adapt the work, but must recognise the authors and the South African Journal of Animal Science.

\begin{abstract}
Muscle metabolites greatly determine pork quality. However, precise threshold values which indicate its deterioration or improvement are not fully known. This study aimed to determine the influences of pork Longissimus lumborum ( $L L$ ) glycogen and lactate concentrations measured at 45 min post mortem on $\mathrm{pH}$, colour $\left(\mathrm{L}^{*} \mathrm{a}^{*} \mathrm{~b}^{*}\right)$ and drip loss (DL) measured during 144 hours post mortem in order to prescribe appropriate threshold values. The investigation used 30 gilts and 30 barrows being fattened for slaughter. After slaughter, the carcasses were assigned to groups based on the observed levels of glycogen and lactate: low GlyL with glycogen $\leq 35 \mu \mathrm{mol} / \mathrm{g}$, GlyM with glycogen between 35 and $55 \mu \mathrm{mol} / \mathrm{g}$, GlyH with glycogen $>55$ $\mu \mathrm{mol} / \mathrm{g}$; LacL with lactate $\leq 40 \mu \mathrm{mol} / \mathrm{g}$ and LacH with lactate $>40 \mu \mathrm{mol} / \mathrm{g}$. Lower muscle $\mathrm{pH}$ was noted up to $24 \mathrm{~h}$ post mortem in the $\mathrm{LacH}$ group compared to $\mathrm{LacL}(P \leq 0.01)$. $24 \mathrm{~h}$ post mortem higher $\mathrm{pH}$ was found in GlyL than in GlyM and GlyH ( $P \leq 0.01)$, which were similar. Similarly no statistical differences were noted between The GlyM and GlyH groups were also similar in $\mathrm{L}^{*}, \mathrm{DL}_{96}$ and $\mathrm{DL}_{144}$, with lower values found for Gly $(P \leq 0.01)$. Compared to $\mathrm{LacH}, \mathrm{LacL}$ had lower $\mathrm{L}^{*}, \mathrm{DL}_{48}, \mathrm{DL}_{96}$ and $\mathrm{DL}_{144}(P \leq 0.01)$ and higher $\mathrm{a}^{*}$ and $\mathrm{b}^{*}$ values. Muscle $\mathrm{pH}$, drip loss, $\mathrm{L}^{*}$ and $\mathrm{a}^{*}$ values were more affected by lactate concentration if the glycogen concentration $\geq 35 \mu \mathrm{mol} / \mathrm{g}$ muscle tissue. Thus, metabolite concentration may be a useful and valuable indicator of pork quality.
\end{abstract}

Keywords: drip loss, glycolytic resources, pork colour, post-mortem muscle metabolism

\# Corresponding author: krystian.tarczynski@uph.edu.pl

\section{Introduction}

Satisfaction of consumers is a crucial part of modern shopping behaviour. Thus, it is necessary to understand their needs and to know the factors that generate these demands (Font-i-Furnols \& Guerrero, 2014). In pork meat, colour, marbling, fat content and drip loss are the most important quality attributes for modern consumers and are known to determine their choices at the point of purchase (Verbeke et al., 2005). Unfortunately, the trend of producing pork that excels in production attributes such as leanness and efficiency at minimal cost has caused meat quality to deteriorate (Lonergan et al., 2001; Dokmanović et al., 2015). The US pork industry loses more than $\$ 100$ million annually due to quality defects (Knox et al., 2008) and the German pork industry loses EUR198 million as a result of a 1\% increase drip loss from the loin (Fischer, 2007).

Thus, proper evaluation of pork quality is of great importance and the mechanisms of its development and especially post-mortem carbohydrate metabolism in the muscle are the subject of increased research efforts (Huff-Lonergan et al., 2002; Pösö \& Puolanne, 2005). During the post-mortem period, glycogen is converted to lactate releasing hydrogen ions $\left(\mathrm{H}^{+}\right)$, which are responsible for proper muscle acidification after slaughter and therefore for muscle protein denaturation and subsequently manifestation of meat quality traits (Hamm, 1977; Scheffler et al., 2013; England et al., 2015). According to Choe et al. (2008), changes in glycogen and lactate concentration may potentially indicate values of pork quality attributes and determine pork quality. However, strict threshold values for these muscle metabolites that may indicate deterioration or improvement in pork quality are not yet fully known. Henckel et al. (2002), identified an initial glycogen concentration of $53 \mu \mathrm{mol} / \mathrm{g}$ as a potential threshold, above which no significant correlation with ultimate $\mathrm{pH}$ was found. 
To the best of the authors' knowledge, there is no other information which identifies threshold values of muscle metabolite concentrations which might indicate potential for pork to attain sufficient levels of acidity or other quality attributes. This information could be used in the development of modern pork quality evaluation techniques, for example Raman and Fourier infrared spectroscopy, which could be applied directly in abattoirs at the pre-rigor stage and used for sorting carcasses (Andersen et al., 2017). Thus, the aim of this study was to determine the influence of glycogen and lactate concentrations in pork Longissimus lumborum (LL) measured at 45 min post mortem on $\mathrm{pH}$, colour and drip loss, measured up to 144 hours after slaughter. Secondly, threshold values for these metabolite concentrations which could be used as indicators of pork quality were sought.

\section{Materials and Methods}

Animal experimental procedures conformed to the scientific and ethical regulations provided in Directive 2010/63/EU and accepted by Siedlce University of Natural Sciences and Humanities. The investigation was carried out using Duroc sired pigs from Landrace-Yorkshire cross sows (30 gilts and 30 barrows) that were being fattened for slaughter. These pigs originated from the same breeder and were of similar live weight (ca. $105 \mathrm{~kg}$ ) and age (ca. 160 days). At the breeding farm, animals were kept under the same environmental conditions (concrete floor) and fed a complete diet (Cargill, Inc.) according to age (25$45 \mathrm{~kg}$ of bodyweight: $13.0 \mathrm{MJ}$ metabolizable energy, $160 \mathrm{~g}$ crude protein, $9.50 \mathrm{~g}$ lysine $/ \mathrm{kg} ; 45-65 \mathrm{~kg}$ of bodyweight: $12.75 \mathrm{MJ} \mathrm{ME}, 150 \mathrm{~g}$ crude protein, $8.50 \mathrm{~g}$ lysine $/ \mathrm{kg}$; and 65 +/- $100 \mathrm{~kg}$ of bodyweight: $12.0 \mathrm{MJ}$ $\mathrm{ME}, 140 \mathrm{~g}$ crude protein, $8.00 \mathrm{~g}$ lysine/ $\mathrm{kg}$ ). Loading was performed in small groups by qualified personnel without use of electrical prods. The pigs were transported at night (approximately $280 \mathrm{~km}$ ) in vehicles that were specifically designed for this purpose. After unloading at the meat plant, the pigs were moved to lairage pens for 2-4 hours and had easy access to fresh water. At slaughter they were moved to a stunning area by trained personnel with paddles and restrained with hydraulically powered equipment. The pigs were stunned electrically using an automatic electrical stunner (MIDAS, Stork RMS, The Netherlands, and INARCO constant voltage system) and exsanguinated in a horizontal position. Carcasses were chilled in a threephase chilling tunnel $\left(-10{ }^{\circ} \mathrm{C}\right.$ for $15 \mathrm{~min} .,-15^{\circ} \mathrm{C}$ for $25 \mathrm{~min}$., and $-5{ }^{\circ} \mathrm{C}$ for $40 \mathrm{~min}$. with air velocity of $3 \mathrm{~m} / \mathrm{s}$ ) and stored at $4^{\circ} \mathrm{C}$ up to 24 hours after slaughter.

The quality of pork (from 45 min to 24 hours post mortem) was evaluated directly in carcasses in the Longissimus lumborum muscle behind the last rib. Meat quality parameters at 48 hours after slaughter were measured in meat samples taken at last rib and first lumbar vertebra. The samples were separated from the bone, external fat and epimysium and then stored in plastic bags at $0-4^{\circ} \mathrm{C}$. Meat quality was evaluated on the basis of these parameters that were measured post mortem: acidity of muscle tissue $(\mathrm{pH})$, drip loss at 48, 96, and 144 hours (DL48, DL96, and DL144, respectively), and colour. The $\mathrm{pH}$ was measured at $35 \mathrm{~min}$. and 2, 3, 24, 48, 96, and 144 hours $\left(\mathrm{pH}_{35}, \mathrm{pH}_{2}, \mathrm{pH}_{3}, \mathrm{pH}_{24}, \mathrm{pH}_{48}, \mathrm{pH}_{96}\right.$, and $\mathrm{pH}_{144}$, respectively) post mortem using a pistol pH-meter MASTER (Draminski, Olsztyn, Poland) with temperature compensation. The meter was calibrated prior to collecting he data with pH 4.64 and 7.00 buffer solutions (Mettler-Toledo, LLC, Columbus, Ohio, USA). The probe was inserted perpendicularly to the long axis of the muscle. Colour was measured following Prange et al. (1977), at 24 hours with a Minolta Chroma Meter (model CR 310, Minolta, Osaka, Japan) using D65 illuminant orifice with the results recorded as lightness $\left(\mathrm{L}^{\star}\right)$, redness $\left(\mathrm{a}^{\star}\right)$, and yellowness $\left(b^{\star}\right)$.

After the first measurement of $\mathrm{pH}\left(\mathrm{pH}_{35}\right), L L$ muscle samples $(1 \mathrm{~g})$ were immersed (up to $45 \mathrm{~min}$ post mortem) in tubes with $10 \mathrm{ml}$ of $0.5 \mathrm{M}$ Perchloric acid and homogenized at $11000 \mathrm{rpm}$ (Ultra-Turrax T25, Janke \& Kunkel IKA ${ }^{\circledR}$ Labortechnik, Cridersville, Ohio, USA) to inhibit glycogen changes in muscles. Samples were stored at $-20{ }^{\circ} \mathrm{C}$ for three weeks. Glycogen concentration was determined according to Dalrymple and Hamm (1973) using amyloglucosidase, which was derived from the yeast Aspergillus niger. Lactate concentration was determined following Bergmeyer (1974) using L-lactate dehydrogenase. The glycolytic potential (GP) was calculated as the sum of 2 [glycogen] + [lactate] according to the simplified formula of Monin \& Sellier (1985) and expressed as $\mu$ mol of lactic acid equivalent per gram of fresh muscle tissue.

The genomic DNA was isolated from white blood cells according to Kawasaki (1990), while the RYR1 C1843T polymorphic site was analysed with a DNA test using the PCR/RFLP method according to Fujii et al. (1991).

To the best of the authors' knowledge, there are no pre-existing precise threshold values of muscle metabolite concentration in the literature. Carcasses were grouped according to three classes for glycogen concentration and two classes for lactate concentration based on their observed distributions and means. For glycogen, these classes were as follows, GlyL: glycogen concentration $\leq 35 \mu \mathrm{mol} / \mathrm{g}$ of muscle tissue; GlyM: glycogen concentration between 35 and $55 \mu \mathrm{mol} / \mathrm{g}$ of muscle tissue; and GlyH: glycogen 
concentration $>55 \mu \mathrm{mol} / \mathrm{g}$ of muscle tissue. For lactate, these classes were as follows, LacL: lactate concentration $\leq 40 \mu \mathrm{mol} / \mathrm{g}$ of muscle tissue; and LacH: lactate concentration $>40 \mu \mathrm{mol} / \mathrm{g}$ of muscle tissue.

Data were analysed by two-way analysis of variance using non-orthogonal contrast in STATISTICA 13.1 (StatSoft, Tulsa, OK, USA). The statistical model included the effect of glycogen concentration (2 degrees of freedom), lactate concentration (1 degree of freedom) and the interaction between them. Data were tested for normality using the Shapiro-Wilk statistic (Shapiro \& Wilk, 1965). Significance of differences between means was calculated using the LSD test.

\section{Results and Discussion}

The average lean meat content of the population was $56.23 \pm 3.50 \%$. Hot carcass weight was $86.80 \pm$ $4.11 \mathrm{~kg}$. None of the pigs had the RYR1 $1^{\top} R Y 1^{\top}$ genotype.

The distributions of lactate and glycogen concentrations were approximately normal. Means and standard deviations for the classifications of the research material are shown in Table 1. In Tarczyński et al. (2018), similar glycogen, lactate and GP were reported for two analogous genetic groups that were differentiated by breed of sire. However, Lebret et al. (2011) noted higher lactate concentration and GP in genetically similar pigs $(49.1 \mu \mathrm{mol} / \mathrm{g}$ and $141.4 \mu \mathrm{mol} / \mathrm{g}$ of muscle tissue, respectively) and crossbreeds from a different sire line $(48.7 \mu \mathrm{mol} / \mathrm{g}$ and $141.6 \mu \mathrm{mol} / \mathrm{g}$ of muscle tissue, respectively). Zybert et al. (2015) also noted similar GP, glycogen, and lactate concentration in purebred Duroc pigs being fattened for slaughter.

Table 1 Means $( \pm S D$ ) of glycogen and lactate concentrations and the glycolytic potential of pork assigned to groups characterized by low, medium and high levels of glycogen, and low and high levels of lactate

\begin{tabular}{|c|c|c|c|c|c|c|c|c|c|}
\hline \multirow{2}{*}{ Trait } & \multicolumn{3}{|c|}{$\begin{array}{c}\text { Glycogen concentration } \\
\text { ranges }(\mu \mathrm{mol} /)\end{array}$} & \multicolumn{2}{|c|}{$\begin{array}{l}\text { Lactate concentration } \\
\text { ranges }(\mu \mathrm{mol} / \mathrm{g})\end{array}$} & \multirow{2}{*}{$\begin{array}{c}\bar{x} \\
\mathrm{n}=60\end{array}$} & \multicolumn{3}{|c|}{ F-statistic } \\
\hline & $\begin{array}{l}\text { GlyL } \\
\mathrm{n}=12\end{array}$ & $\begin{array}{l}\text { GlyM } \\
\mathrm{n}=36\end{array}$ & $\begin{array}{l}\text { GlyH } \\
\mathrm{n}=12\end{array}$ & $\begin{array}{l}\text { LacL } \\
\mathrm{n}=29\end{array}$ & $\begin{array}{l}\mathrm{LacH} \\
\mathrm{n}=31\end{array}$ & & Gly & Lac & $\begin{array}{c}\text { (Gly } \\
\times \\
\text { Lac) }\end{array}$ \\
\hline $\begin{array}{c}\text { Glycogen } \\
\text { concentration } \\
(\mu \mathrm{mol} / \mathrm{g})\end{array}$ & $\begin{array}{l}28.72^{\mathrm{A}} \\
\pm 4.54\end{array}$ & $\begin{array}{c}45.33^{\mathrm{B}} \\
\pm 6.06\end{array}$ & $\begin{array}{l}61.17^{\mathrm{C}} \\
\pm 5.15\end{array}$ & $\begin{array}{c}46.67 \\
\pm 10.11\end{array}$ & $\begin{array}{c}43.77 \\
\pm 12.31\end{array}$ & $\begin{array}{c}45.17 \\
\pm 10.73\end{array}$ & $95.32^{\star \star}$ & 0.04 & 0.84 \\
\hline $\begin{array}{c}\text { Lactate } \\
\text { concentration } \\
(\mu \mathrm{mol} / \mathrm{g})\end{array}$ & $\begin{array}{l}41.81 \\
\pm 8.67\end{array}$ & $\begin{array}{c}41.40 \\
\pm 10.31\end{array}$ & $\begin{array}{l}35.33 \\
\pm 7.60\end{array}$ & $\begin{array}{l}32.18^{\mathrm{A}} \\
\pm 4.23\end{array}$ & $\begin{array}{c}47.87^{\mathrm{B}} \\
\pm 6.69\end{array}$ & $\begin{array}{l}40.29 \\
\pm 9.71\end{array}$ & 3.09 & $77.47^{\star \star}$ & 0.63 \\
\hline $\begin{array}{l}\text { Glycolytic } \\
\text { potential } \\
(\mu \mathrm{mol} / \mathrm{g})\end{array}$ & $\begin{array}{l}99.34^{\mathrm{A}} \\
\pm 11.75\end{array}$ & $\begin{array}{c}132.06^{\mathrm{B}} \\
\pm 14.53\end{array}$ & $\begin{array}{c}157.68^{\mathrm{C}} \\
\pm 14.87\end{array}$ & $\begin{array}{l}125.51^{\mathrm{A}} \\
\pm 21.30\end{array}$ & $\begin{array}{l}135.43^{B} \\
\pm 24.33\end{array}$ & $\begin{array}{l}130.64 \\
\pm 23.27\end{array}$ & $69.65^{\star *}$ & $13.93^{\star *}$ & 0.47 \\
\hline
\end{tabular}

${ }_{A, B, C}$ Within a row, means with a common superscript do not differ significantly at $P \leq 0.01$, * $P \leq 0.01$

Gly: glycogen; Lac: lactate; GlyL: $\leq 35 \mu \mathrm{mol}$ glycogen per $\mathrm{g}$ of muscle tissue; GlyM: glycogen concentration between 35 and $55 \mu \mathrm{mol}$ per $\mathrm{g}$ of muscle tissue; $\mathrm{GlyH}$ : $>55 \mu \mathrm{mol}$ glycogen per $\mathrm{g}$ of muscle tissue; LacL: $\leq 40 \mu \mathrm{mol}$ lactate per $\mathrm{g}$ of muscle tissue); $\mathrm{LacH}:>40 \mu \mathrm{mol}$ lactate per $\mathrm{g}$ of muscle tissue

Glycolytic resources in pre-rigor muscle influence muscle acidity after slaughter. According to Van Laack (2000), GP explains the $42 \%$ of variation in ultimate pH. Zybert et al. (2014) showed that the concentrations of glycogen and lactate measured at $45 \mathrm{~min}$. after slaughter were indicative of $\mathrm{pH}$ decline up to 48 hours post mortem. Additionally, if glycogen level at the slaughter is low, higher concentration of lactate can indicate faster glycolysis and therefore lower pH at early post-mortem period (Koćwin-Podsiadła et al., 2006). The effects of glycogen and lactate concentration on $\mathrm{pH}$ measured up to 144 hours post mortem are shown in Table 2. Ryu and Kim (2005) and Lebret et al. (2011) noted lower pH values at 45 min after slaughter (6.02 \pm 0.26 and 6.40, respectively) than were observed in the present study. Similar $\mathrm{pH}_{35}(6.58 \pm$ $0.15)$ and lower $\mathrm{pH}_{3}(5.91 \pm 0.19)$ were noted by Rybarczyk et al. (2018). Zhang et al. (2018) also found a similar pH value at $45 \mathrm{~min}$ after slaughter (6.55 \pm 0.07$)$. Lebret et al. (2011), Ryu and Kim (2005), and Zhang et al. (2018) all found lower $\mathrm{pH}_{24}(5.56,5.57 \pm 0.12$ and $5.58 \pm 0.14$, respectively) in pork from Duroc sired pigs out of Landrace-Yorkshire cross bred sows than was noted in this study. Similar values of pH measured at 24 hours $(5.65 \pm 0.16)$, and higher at 48 hours $(5.72 \pm 0.20)$ and 96 hours (5.68 \pm 0.14$)$ after slaughter, were noted by Rybarczyk et al. (2018). 
Table 2 Means $( \pm S D)$ of $\mathrm{pH}$ of pork measured between 35 minutes and 144 hours post mortem as related to its levels of glycogen and lactate at 45 minutes post mortem

\begin{tabular}{|c|c|c|c|c|c|c|c|c|c|}
\hline \multirow{2}{*}{ Trait } & \multicolumn{3}{|c|}{$\begin{array}{l}\text { Glycogen concentration } \\
\text { ranges }(\mu \mathrm{mol} / \mathrm{g})\end{array}$} & \multicolumn{2}{|c|}{$\begin{array}{l}\text { Lactate concentration ranges } \\
{[\mu \mathrm{mol} / \mathrm{g}]}\end{array}$} & \multirow{2}{*}{$\begin{array}{c}\bar{x} \\
\mathrm{n}=60\end{array}$} & \multicolumn{3}{|c|}{ F-statistic } \\
\hline & $\begin{array}{c}\text { GlyL } \\
\mathrm{n}=12\end{array}$ & $\begin{array}{c}\text { GlyM } \\
\mathrm{n}=36\end{array}$ & $\begin{array}{c}\text { GlyH } \\
n=12\end{array}$ & $\begin{array}{c}\text { LacL } \\
\mathrm{n}=29\end{array}$ & $\begin{array}{l}\mathrm{LaCH} \\
\mathrm{n}=31\end{array}$ & & Gly & Lac & $\begin{array}{l}\text { Gly } \times \\
\text { Lac }\end{array}$ \\
\hline $\mathrm{pH}_{35}$ & $\begin{array}{c}6.63 \pm \\
0.18\end{array}$ & $\begin{array}{l}6.60 \pm \\
0.15\end{array}$ & $\begin{array}{c}6.67 \pm \\
0.16\end{array}$ & $6.68^{B} \pm 0.16$ & $6.57^{A} \pm 0.12$ & $\begin{array}{c}6.62 \pm \\
0.16\end{array}$ & 0.79 & $14.67^{\star * *}$ & $3.81^{* *}$ \\
\hline $\mathrm{pH}_{2}$ & $\begin{array}{c}6.43 \pm \\
0.14\end{array}$ & $\begin{array}{c}6.44 \pm \\
0.18\end{array}$ & $\begin{array}{c}6.56 \pm \\
0.18\end{array}$ & $6.55^{B} \pm 0.17$ & $6.37^{\mathrm{A}} \pm 0.14$ & $\begin{array}{c}6.45 \pm \\
0.18\end{array}$ & 0.97 & $15.07^{* *}$ & 1.14 \\
\hline $\mathrm{pH}_{3}$ & $\begin{array}{c}6.27 \pm \\
0.17\end{array}$ & $\begin{array}{c}6.24 \pm \\
0.19\end{array}$ & $\begin{array}{l}6.35 \pm \\
0.22\end{array}$ & $6.38^{B} \pm 0.18$ & $6.18^{A} \pm 0.15$ & $\begin{array}{c}6.27 \pm \\
0.19\end{array}$ & 0.82 & $19.23^{\star \star}$ & 0.72 \\
\hline $\mathrm{pH}_{24}$ & $\begin{array}{l}5.81^{\mathrm{B}} \pm \\
0.14\end{array}$ & $\begin{array}{l}5.67^{\mathrm{A}} \pm \\
0.08\end{array}$ & $\begin{array}{c}5.65^{\mathrm{A}} \pm \\
0.11\end{array}$ & $5.74^{B} \pm 0.10$ & $5.64^{A} \pm 0.11$ & $\begin{array}{c}5.69 \pm \\
0.11\end{array}$ & $17.9^{\star \star}$ & $24.90^{* *}$ & 1.20 \\
\hline $\mathrm{pH}_{48}$ & $\begin{array}{l}5.63^{B} \pm \\
0.15\end{array}$ & $\begin{array}{l}5.46^{\mathrm{A}} \pm \\
0.07\end{array}$ & $\begin{array}{l}5.43^{A} \pm \\
0.06\end{array}$ & $5.50 \pm 0.11$ & $5.48 \pm 0.11$ & $\begin{array}{c}5.49 \pm \\
0.11\end{array}$ & $20.8^{\star \star}$ & 3.00 & 1.20 \\
\hline $\mathrm{pH}_{96}$ & $\begin{array}{l}5.56^{\mathrm{B}} \pm \\
0.16\end{array}$ & $\begin{array}{l}5.39^{A} \pm \\
0.07\end{array}$ & $\begin{array}{l}5.35^{A} \pm \\
0.04\end{array}$ & $5.43 \pm 0.11$ & $5.40 \pm 0.12$ & $\begin{array}{c}5.41 \pm \\
0.12\end{array}$ & $19.4^{\star \star}$ & 2.60 & 0.81 \\
\hline $\mathrm{pH}_{144}$ & $\begin{array}{l}5.75^{\mathrm{B}} \pm \\
0.18\end{array}$ & $\begin{array}{l}5.46^{\mathrm{A}} \pm \\
0.07\end{array}$ & $\begin{array}{l}5.41^{A} \pm \\
0.06\end{array}$ & $5.51 \pm 0.12$ & $5.51 \pm 0.14$ & $\begin{array}{c}5.51 \pm \\
0.16\end{array}$ & $44.6^{* *}$ & 2.80 & 1.80 \\
\hline
\end{tabular}

${ }^{A, B}$ Within a row, means with a common superscript do not differ significantly at $P \leq 0.01,{ }^{\star} P \leq 0.01$

Gly: glycogen; Lac: lactate; GlyL: $\leq 35 \mu \mathrm{mol}$ glycogen per g of muscle tissue; GlyM: glycogen concentration between 35 and $55 \mu \mathrm{mol}$ per $\mathrm{g}$ of muscle tissue; $\mathrm{GlyH}:>55 \mu \mathrm{mol}$ glycogen per $\mathrm{g}$ of muscle tissue; LacL: $\leq 40 \mu \mathrm{mol}$ lactate per $\mathrm{g}$ of muscle tissue); LacH: $>40 \mu \mathrm{mol}$ lactate per $\mathrm{g}$ of muscle tissue; $\mathrm{pH}_{35}, \mathrm{pH}_{2}, \mathrm{pH}_{3}, \mathrm{pH}_{24}, \mathrm{pH}_{48}, \mathrm{pH}_{96}$, and $\mathrm{pH} \mathrm{H}_{144}$ : $\mathrm{pH}$ at 35 $\min , 2,3,24,48,96$, and 144 hours post mortem

In the present study, the initial glycogen level, independent of the lactate concentration, determined $\mathrm{pH}$ measured at 24 hours post mortem onward, but not pre-rigor. No differences in $\mathrm{pH}$ measured at 24 hours after slaughter were noted between GlyM and GlyH groups; a finding which is some respects similar to the results of Sheffler et al. (2013). These authors found that GP was indirectly related to the extent of $\mathrm{pH}$ decline. However, Sheffler et al. (2013) did not examine glycogen and lactate concentrations separately but showed that different $\mathrm{pH}_{24}$ could be obtained in meat with similar (normal) GP and potentially similar glycogen concentrations. Lactate concentration, independently of glycogen level, differentiated pH measured up to 24 hour post mortem with significantly higher $\mathrm{pH}$ values being obtained in LacL group (Table 2). Van Laack and Kauffmann (1999) also showed that muscles with similar lactate concentration may have different ultimate pH levels. In the study by Dokmanović et al. (2015), higher pH measured at 60 min after slaughter $(P \leq 0.01)$ was noted in the group with lower lactate concentration $(<12 \mathrm{mmol} / \mathrm{g}$ vs $>12 \mathrm{mmol} / \mathrm{g})$. However, in this study, lactate concentration was determined in blood samples. No interaction of glycogen and lactate concentrations affecting $\mathrm{pH}$ was seen in the present study, other than for its initial value measured at $35 \mathrm{~min}$ post mortem (Table 2).

The effect of the lactate level on $\mathrm{pH}$ measured up to 144 hours post-mortem within the GlyL, GlyM and $\mathrm{GlyH}$ groups are presented in Figures 1-3. Overall, lower lactate concentration was connected with more favourable $\mathrm{pH}$ values measured up to 24 hours post mortem within analysed glycogen ranges.

In a study by Choe et al. (2008), lactate level differentiated $(P \leq 0.05) \mathrm{pH}$ measured after slaughter at $45 \mathrm{~min}$, but not at 24 hours post-mortem among meat samples with high glycogen concentration. These authors found no differences in $\mathrm{pH}_{45}$ and $\mathrm{pH}_{24}$ values between low and high lactate concentration groups when the glycogen level was low, which was the opposite of the results obtained in the present survey (Figure 1). In addition, it might be that lactate differentiates $\mathrm{pH}$ changes up to 24 hours post mortem to a lesser degree if the glycogen level is low and to a greater degree if the glycogen concentration is high. England et al. (2016) showed that oxidative muscles produce high $\mathrm{pH}_{24}$ even in the presence of excess glycogen. However, in England et al. (2016) low $\mathrm{pH}_{24}$ (ca. 5.4 units) was found in the LL muscle with the initial glycogen level between 30 and $35 \mu \mathrm{mol} / \mathrm{g}$ of muscle tissue. In the present study, the average $\mathrm{pH}_{24}$ value of $5.65 \pm 0.11$ was obtained even for those samples in which the glycogen level at 45 min after slaughter was higher than $55 \mu \mathrm{mol} / \mathrm{g}$ of muscle tissue (Table 2). Choe et al. (2008) observed that $\mathrm{pH}_{24} \mathrm{Was}$ greater than 5.54 units, regardless of glycogen and lactate concentration, except in groups characterized by high glycogen and high lactate concentrations wherein it was reduced (5.43) As suggested by England et al. (2014), the reason for normal $\mathrm{pH}_{24}$ values, despite the high glycogen level at 45 min post mortem, could be the loss of phosphofructokinase activity. 
GlyL (n=12)

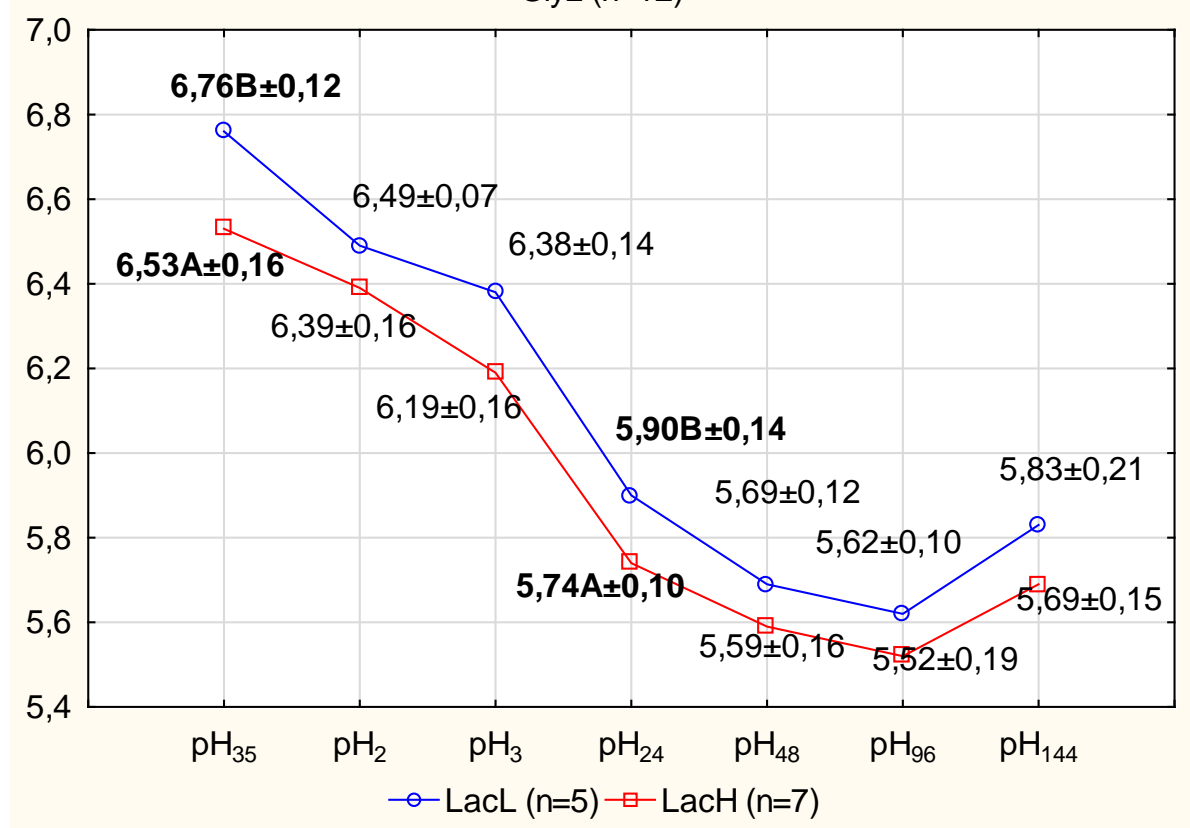

Figure 1 The effect of lactate concentration in muscle on $\mathrm{pH}$ up to 144 hours post mortem in pigs characterized by low glycogen concentration

A,B: At each time-point, means followed by different letters are significantly different at $P \leq 0.01$

GlyL: glycogen $\leq 35 \mu \mathrm{mol} / \mathrm{g}$; LacL: lactate $\leq 40 \mu \mathrm{mol} / \mathrm{g}$; LacH: lactate $>40 \mu \mathrm{mol} / \mathrm{g}$

$\mathrm{pH}_{35}, \mathrm{pH}_{2}, \mathrm{pH}_{3}, \mathrm{pH}_{24}, \mathrm{pH}_{48}, \mathrm{pH}_{96}, \mathrm{pH}_{144}$ : $\mathrm{pH}$ measured at 35 min., 2, 3, 24, 48, 96 and 144 hours post mortem

$\operatorname{GlyM}(n=36)$

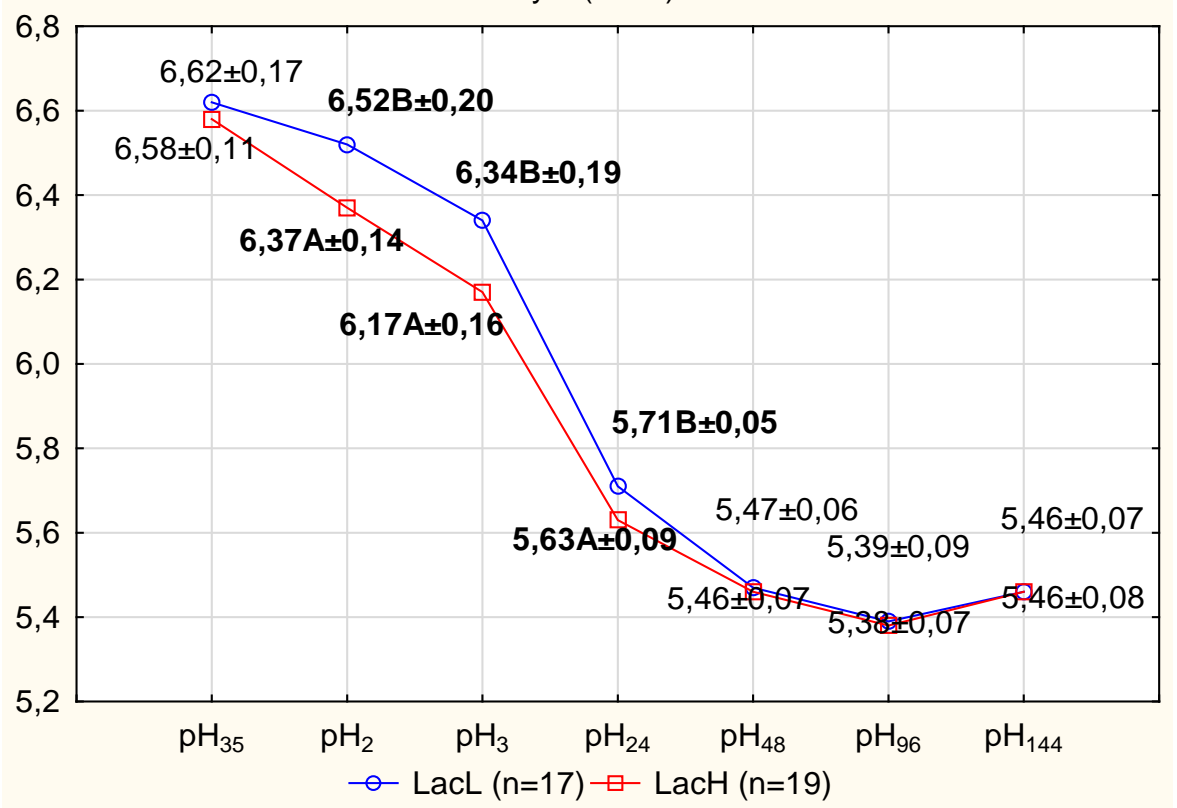

Figure 2 The effect of lactate concentration in muscle on $\mathrm{pH}$ up to 144 hours post mortem in pigs characterized by intermediate glycogen concentration

A,B: At each time-point, means followed by different letters are significantly different at $P \leq 0.01$

GlyM: glycogen concentration between 35 and $55 \mu \mathrm{mol} / \mathrm{g}$ of muscle tissue; LacL: lactate concentration $\leq 40$ $\mu \mathrm{mol} / \mathrm{g}$ of muscle tissue; $\mathrm{LacH}$ : lactate concentration $>40 \mu \mathrm{mol} / \mathrm{g}$ of muscle tissue

$\mathrm{pH}_{35}, \mathrm{pH}_{2}, \mathrm{pH}_{3}, \mathrm{pH}_{24}, \mathrm{pH}_{48}, \mathrm{pH}_{96}, \mathrm{pH}_{144}$ : $\mathrm{pH}$ measured at 35 min., 2, 3, 24, 48, 96 and 144 hours post mortem 


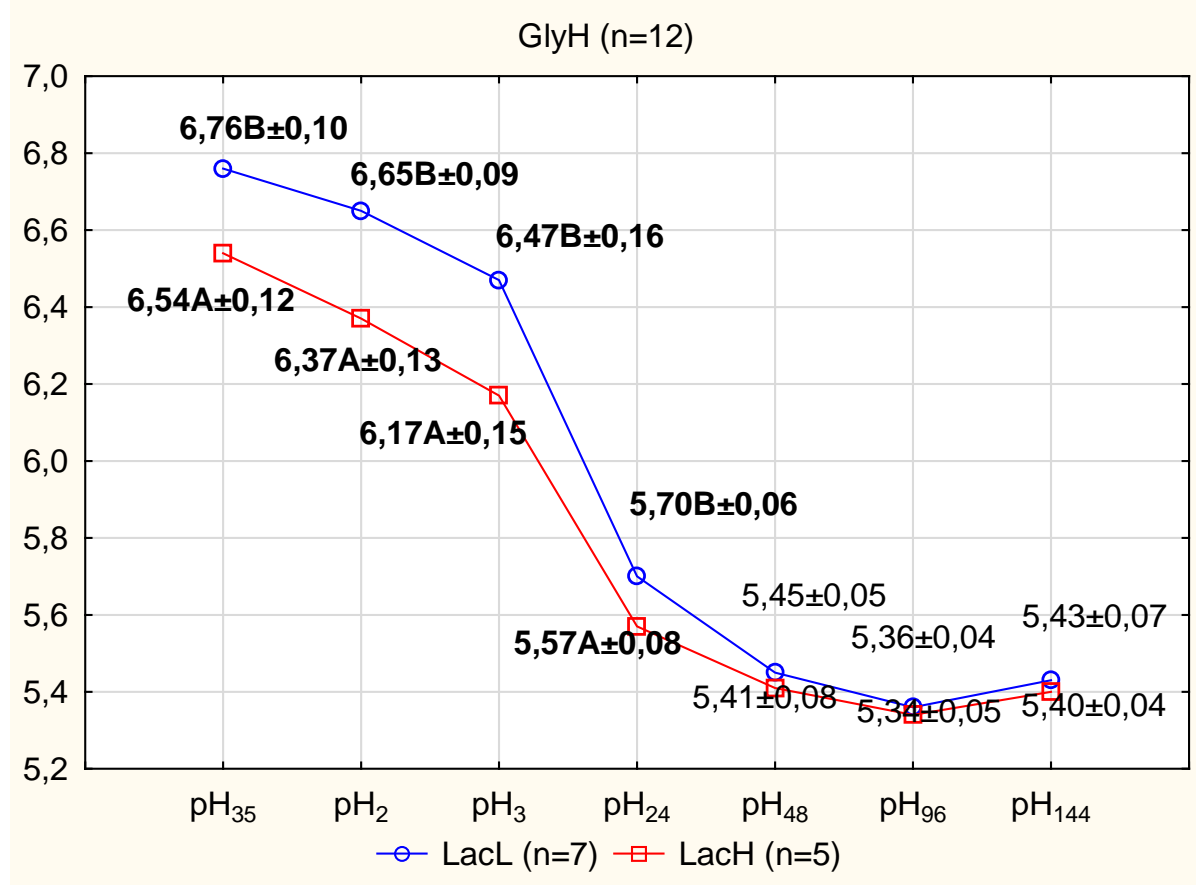

Figure 3 The effect of lactate concentration in muscle on pH up to 144 hours post mortem in pigs characterized by high glycogen concentration

A,B: At each time-point, means followed by different letters are significantly different at $P \leq 0.01$

GlyL: glycogen $>55 \mu \mathrm{mol} / \mathrm{g}$; LacL: lactate $\leq 40 \mu \mathrm{mol} / \mathrm{g}$; LacH: lactate $>40 \mu \mathrm{mol} / \mathrm{g}$

$\mathrm{pH}_{35}, \mathrm{pH}_{2}, \mathrm{pH}_{3}, \mathrm{pH}_{24}, \mathrm{pH}_{48}, \mathrm{pH}_{96}, \mathrm{pH}_{144}$ : $\mathrm{pH}$ measured at 35 min., 2, 3, 24, 48, 96 and 144 hours post mortem

Shown in Table 3 are the colour values $L^{*}, a^{*}$ and $b^{*}$ of the meat samples. Glycogen concentration, independent of lactate level, differentiated $L^{*}$ values. Significantly higher $L^{*}$ values were noted in $\mathrm{GlyH}$ group than in GlyL group. Lactate concentration, independent of glycogen level, differentiated $L^{*}$ and $a^{*}$ values $(P$ $\leq 0.01)$ and $\mathrm{b}^{*}$ value $(P \leq 0.05)$. More favourable values of aforementioned parameters were noted in LacL group. No interaction effect was found between glycogen and lactate concentration for $L^{*}, a^{*}$, and $b^{*}$ values. Choe et al. (2008) observed that higher $L^{*}$ was associated with higher lactate concentration in both low and high glycogen concentration groups. The average $L^{*}$ value observed here was similar to those noted by Tarczyński et al. (2018) in two groups of pigs being fattened for slaughter and by Zybert et al. (2015) in purebred Duroc. Other studies using crosses of Duroc boars on Landrace-Yorkshire sows have found variable results relative to the present study. Lebret et al. (2011) observed a similar value of $b^{\star}$, a slightly higher value of $L^{*}(55.4)$, but notably lower value of $a^{*}$. Slightly higher values of $L^{*}(55.24 \pm 2.78)$, and notably lower $a^{*}(5.10 \pm 1.06)$ and higher $b^{*}(13.34 \pm 0.60)$ values were found by Rybarczyk et al. $(2018)$. Ryu \& Kim (2005) noted values that generally indicated less intense colour $\left(L^{*}: 47.25 \pm 3.52 ; a^{*}: 6.95 \pm 1.26\right.$; and $b^{*}: 3.98$ \pm 1.11 ). Finally, Zhang et al. (2018) observed values of $L^{*}, a^{*}$ and $b^{*}$ of $46.29 \pm 1.37,8.25 \pm 0.31$ and $6.09 \pm$ 0.32 , respectively.

Drip loss is currently regarded as a primary concern for the meat industry owing to the financial losses that result from it (Fischer, 2007; Otto et al., 2007). The impact of glycogen and lactate concentration on drip loss is shown in Table 4. Ryu and Kim (2005) and Zhang et al. (2018) found less drip loss at 48 hours post mortem ( $4.71 \pm 2.55 \%$ and $3.63 \pm 0.15 \%$, respectively) than was observed in this study. Much lower $\mathrm{DL}_{48}$ $(2.19 \pm 0.99 \%)$ and $\mathrm{DL}_{96}(4.37 \pm 1.75)$ values were noted by Rybarczyk et al. (2018). 
Table 3 Means $( \pm S D)$ of the colour values of pork for average effects of glycogen and lactate concentrations

\begin{tabular}{|c|c|c|c|c|c|c|c|c|c|}
\hline \multirow{2}{*}{ Colour } & \multicolumn{3}{|c|}{$\begin{array}{c}\text { Glycogen concentration } \\
\text { ranges }[\mu \mathrm{mol} / \mathrm{g}]\end{array}$} & \multicolumn{2}{|c|}{ Lactate concentration ranges $[\mu \mathrm{mol} / \mathrm{g}]$} & \multirow{2}{*}{$\begin{array}{c}\bar{x} \\
\mathrm{n}=60\end{array}$} & \multicolumn{3}{|c|}{ F-statistic } \\
\hline & $\begin{array}{c}\text { GlyL } \\
\mathrm{n}=12\end{array}$ & $\begin{array}{c}\text { GlyM } \\
\mathrm{n}=36\end{array}$ & $\begin{array}{c}\text { GlyH } \\
\mathrm{n}=12\end{array}$ & $\begin{array}{c}\text { LacL } \\
\mathrm{n}=29\end{array}$ & $\begin{array}{l}\mathrm{LacH} \\
\mathrm{n}=31\end{array}$ & & Gly & Lac & Gly $\times$ Lac \\
\hline Lightness $\left(L^{\star}\right)$ & $52.36^{A} \pm 2.62$ & $54.36^{\mathrm{AB}} \pm 2.50$ & $55.69^{B} \pm 2.95$ & $53.09^{A} \pm 2.70$ & $55.28^{B} \pm 2.47$ & $54.23 \pm 2.78$ & $7.29^{\star \star}$ & $10.70^{\star \star}$ & $1.10^{\mathrm{NS}}$ \\
\hline Redness $\left(a^{\star}\right)$ & $14.40 \pm 1.49$ & $14.38 \pm 1.29$ & $14.04 \pm 1.47$ & $14.84^{B} \pm 1.63$ & $13.82^{\mathrm{A}} \pm 0.77$ & $14.32 \pm 1.35$ & $0.63^{\mathrm{NS}}$ & $8.25^{\star \star}$ & $0.22^{\mathrm{NS}}$ \\
\hline Yellowness $\left(b^{\star}\right)$ & $5.38 \pm 1.99$ & $5.12 \pm 1.51$ & $5.34 \pm 1.06$ & $5.63^{b} \pm 1.99$ & $4.84^{a} \pm 0.73$ & $5.22 \pm 1.52$ & $0.32^{\mathrm{NS}}$ & $3.87^{\star}$ & $1.12^{\mathrm{NS}}$ \\
\hline
\end{tabular}

${ }_{A, B}$ With a row, means with a common superscript do not differ significantly at $P \leq 0.01$

a,b With a row, means with a common superscript do not differ significantly at $P \leq 0.05$

* $P \leq 0.05$, ** $P \leq 0.01$, NS $P>0.05$

Gly: glycogen; Lac: lactate; GlyL: $\leq 35 \mu \mathrm{mol}$ glycogen per g of muscle tissue; GlyM: glycogen between 35 and $55 \mu \mathrm{mol}$ per g of muscle tissue; GlyH: $>55 \mu \mathrm{mol}$ glycogen per $\mathrm{g}$ of muscle tissue; LacL: $\leq 40 \mu \mathrm{mol}$ lactate per $\mathrm{g}$ of muscle tissue); LacH: $>40 \mu \mathrm{mol}$ lactate per $\mathrm{g}$ of muscle tissue

Table 4 Means $( \pm S D)$ of drip loss measured at 48,96 and 144 hours post mortem from pork differing in levels of glycogen and lactate

\begin{tabular}{|c|c|c|c|c|c|c|c|c|c|}
\hline \multirow{2}{*}{ Drip Loss (hours) } & \multicolumn{3}{|c|}{$\begin{array}{c}\text { Glycogen concentration } \\
\text { ranges }[\mu \mathrm{mol} / \mathrm{g}]\end{array}$} & \multicolumn{2}{|c|}{ Lactate concentration ranges $[\mu \mathrm{mol} / \mathrm{g}]$} & \multirow{2}{*}{$\begin{array}{c}\bar{x} \\
\mathrm{n}=60\end{array}$} & \multicolumn{3}{|c|}{ F-statistic } \\
\hline & $\begin{array}{c}\text { GlyL } \\
\mathrm{n}=12\end{array}$ & $\begin{array}{c}\text { GlyM } \\
\mathrm{n}=36\end{array}$ & $\begin{array}{c}\text { GlyH } \\
\mathrm{n}=12\end{array}$ & $\begin{array}{l}\text { LacL } \\
\mathrm{n}=29\end{array}$ & $\begin{array}{l}\mathrm{LacH} \\
\mathrm{n}=31\end{array}$ & & Gly & Lac & $($ Gly $\times$ Lac $)$ \\
\hline 48 & $4.23 \pm 2.39$ & $5.43 \pm 2.23$ & $6.04 \pm 2.56$ & $4.45^{A} \pm 1.73$ & $6.12^{B} \pm 2.61$ & $5.31 \pm 2.37$ & $2.94^{\mathrm{NS}}$ & $9.25^{\star \star}$ & $0.41^{N S}$ \\
\hline 96 & $6.37^{A} \pm 2.88$ & $8.82^{B} \pm 2.34$ & $9.47^{B} \pm 2.60$ & $7.22^{A} \pm 2.02$ & $9.61^{B} \pm 2.76$ & $8.46 \pm 2.69$ & $8.63^{\star \star}$ & $16.19^{* *}$ & $0.16^{\mathrm{NS}}$ \\
\hline 144 & $8.48^{A} \pm 3.12$ & $11.83^{B} \pm 2.55$ & $11.89^{B} \pm 2.67$ & $9.96^{\mathrm{A}} \pm 2.64$ & $12.29^{B} \pm 2.86$ & $11.17 \pm 2.97$ & $10.73^{\star \star}$ & $15.81^{\star *}$ & $0.47^{\mathrm{NS}}$ \\
\hline
\end{tabular}

${ }_{\mathrm{A}, \mathrm{B}}$ With a row, means with a common superscript do not differ significantly at $P \leq 0.01$

** $P \leq 0.01, \mathrm{NS} P>0.05$

Gly: glycogen; Lac: lactate; GlyL: $\leq 35 \mu \mathrm{mol}$ glycogen per g of muscle tissue; GlyM: glycogen concentration between 35 and $55 \mu \mathrm{mol}$ per g of muscle tissue; GlyH: $>55 \mu \mathrm{mol}$ glycogen per $\mathrm{g}$ of muscle tissue; LacL: $\leq 40 \mu \mathrm{mol}$ lactate per $\mathrm{g}$ of muscle tissue); LacH: $>40 \mu \mathrm{mol}$ lactate per $\mathrm{g}$ of muscle tissue 
Glycogen concentration, independent of lactate level, differentiated drip loss at 96 and 144 hours post mortem. Significantly higher $\mathrm{DL}_{96}$ and $\mathrm{DL}_{144}$ values were achieved in the GlyM and GlyH groups. Lactate concentration, independent of glycogen level, differentiated drip loss at all time-points. More favourable values, lower drip losses, were noted in the LacL group. No interaction effect was found between glycogen and lactate concentration for drip loss (Table 5). The effect of lactate concentration on drip loss within GlyL, GlyM, and GlyH was presented in Figures 4-6. Significantly lower drip loss in all time-points was noted in LacL group, however only within GlyM and GlyH groups. In Choe et al. (2008), DL 48 values were not statistically different between low lactate and high lactate concentration groups when the glycogen level was low. However, Choe et al. (2008) also found relatively insignificant differences $(P<0.1)$ in $\mathrm{DL}_{48}$ values between low lactate and high lactate concentration groups if glycogen level was high despite these differences being rather considerable, for example $2.5 \%$. This leads to the conclusion that the impact of lactate level on DL measured up to 144 hours post mortem is higher if the glycogen level is at least moderate.

GlyL (n=12)

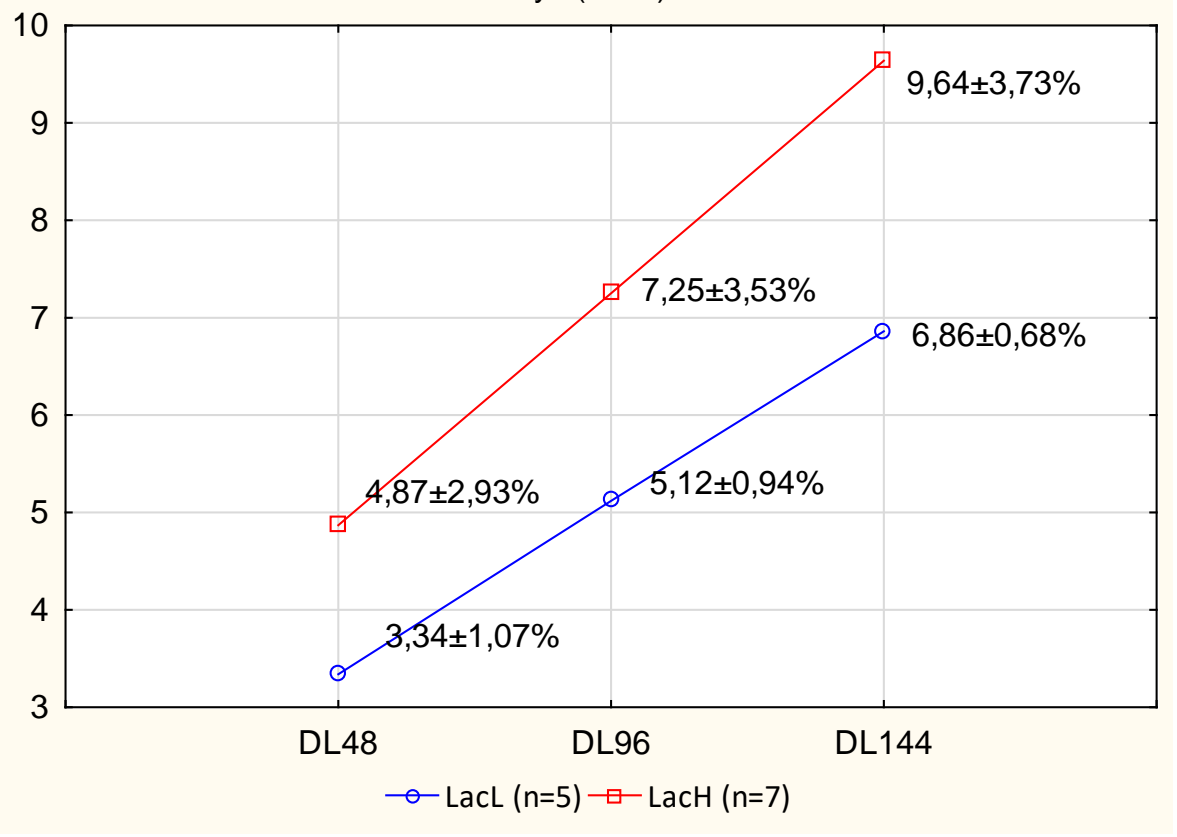

Figure 4 The effect of lactate concentration in muscle on drip loss measured at 48, 96 and 144 hour post mortem in pigs characterized by low glycogen concentration

GlyL - glycogen $\leq 35 \mu \mathrm{mol} / \mathrm{g}$; LacL - lactate $\leq 40 \mu \mathrm{mol} / \mathrm{g} ;$ LacH - lactate $>40 \mu \mathrm{mol} / \mathrm{g} ; \mathrm{DL}_{48}$, DL96, DL 144 : drip loss measured at 48, 96 and 144 hour post mortem 


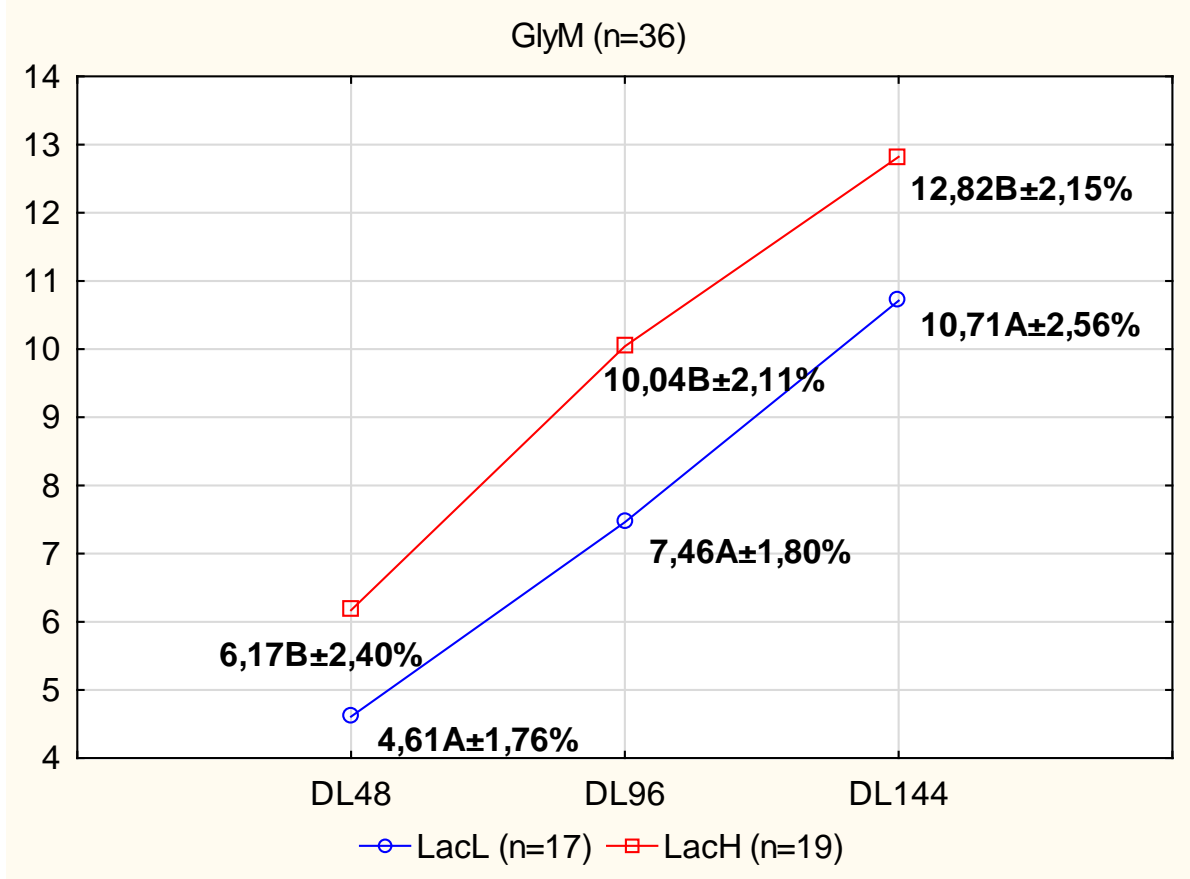

Figure 5 The effect of lactate concentration in muscle on drip loss measured at 48, 96 and 144 hour post mortem in pigs characterized by intermediate glycogen concentration

GlyL - glycogen $\leq 35 \mu \mathrm{mol} / \mathrm{g} ;$ LacL - lactate $\leq 40 \mu \mathrm{mol} / \mathrm{g} ; \mathrm{LacH}$ - lactate $>40 \mu \mathrm{mol} / \mathrm{g} ; \mathrm{DL}_{48}$, DL96, DL 144 : drip loss measured at 48, 96 and 144 hour post mortem

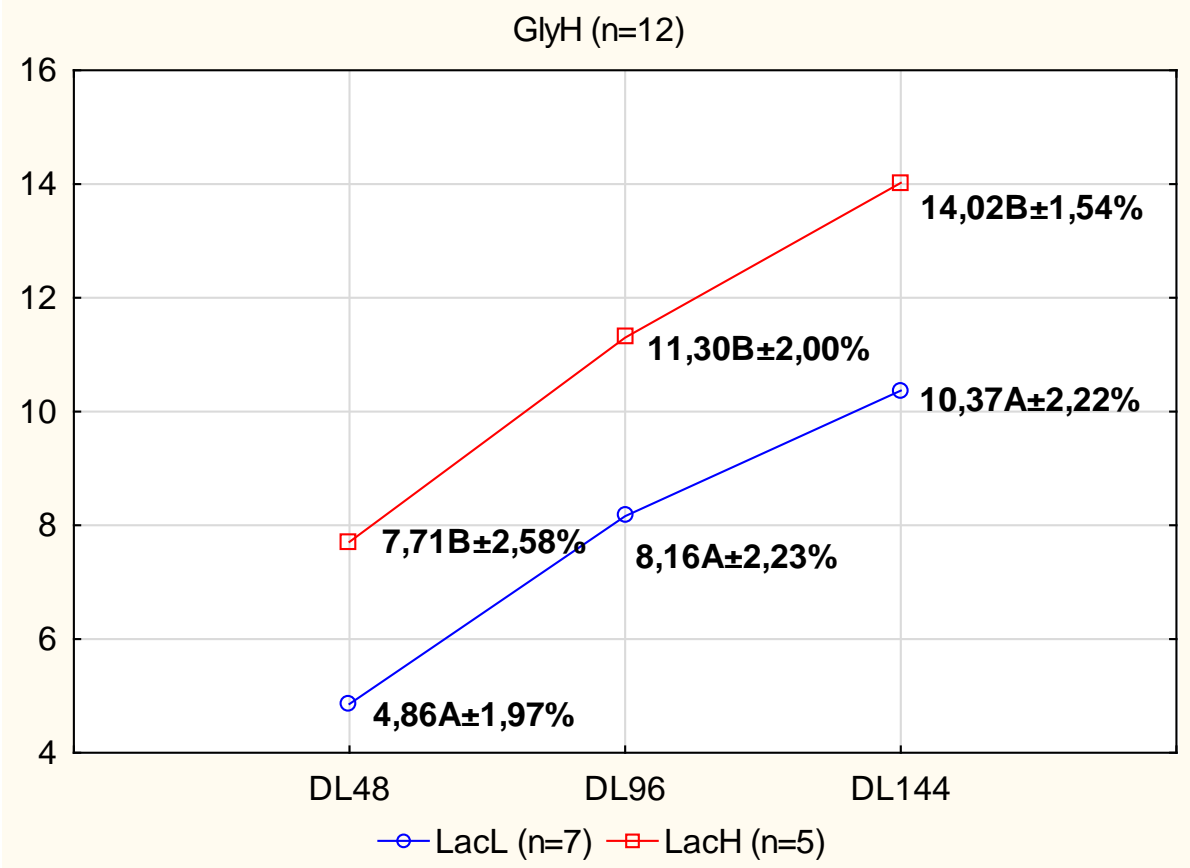

Figure 6 The effect of lactate concentration in muscle on drip loss measured at 48, 96 and 144 hour post mortem in pigs characterized by high glycogen concentration

GlyL - glycogen $\leq 35 \mu \mathrm{mol} / \mathrm{g} ;$ LacL - lactate $\leq 40 \mu \mathrm{mol} / \mathrm{g}$; LacH - lactate $>40 \mu \mathrm{mol} / \mathrm{g} ; \mathrm{DL}_{48}, \mathrm{DL}_{96}, \mathrm{DL}_{144}$ : drip loss measured at 48,96 and 144 hour post mortem 
Although muscle metabolite concentrations and their relationship could possibly be used as pork quality indicators, some limitations may occur due to mechanisms of post-mortem metabolism not being fully understood. According to Shäfer et al. (2002) to explain $89 \%$ of the variation in drip loss, $\mathrm{pH}$ and temperature measurements at significant time points were sufficient. Variation in post-mortem metabolites did, however, explain why variation in $\mathrm{pH}$ and temperature occurred. Additionally, mechanisms that control pork quality development are associated not only with post-mortem muscle metabolism, but also with the chilling and stunning method (Zybert et al., 2019), transportation and stress (Henckel et al., 2002; Hambrecht et al., 2005), and variations in temperature (combination of high temperature and low pH appears as pale, soft, exudative meat (Pearson \& Young, 1989).

Additionally, in the present survey the relatively small number of samples could be the limiting factor in precise determination of muscle metabolite threshold values. This study was carried out using exclusively Duroc sired pigs out of Landrace-Yorkshire crossbred sows which is a popular commercial cross. Thus, the results might be different in other crossbreds. This could be especially relevant to the Hampshire breed, in which the frequency of the $\mathrm{RN}^{-}$allele is relatively high and when homozygous can result in a low and dramatic drop in meat $\mathrm{pH}$ due to its high glycogen muscle content post mortem (Monin \& Sellier, 1985). This rapid drop in $\mathrm{pH}$ leads to breakdown in protein resulting in pale muscle colour and increased DL. Another breed to which these concerns may be of particular importance is the Piétrain, a known carrier of the RYR1 allele. This allele is also associated with post-slaughter metabolism in met thus accelerating the post-mortem decline of $\mathrm{pH}$. Moreover, in the survey by Tarczyński et al. (2018), significant changes in post-mortem metabolism that occurs during ageing were suggested and could possibly be relevant to commercial pork production as well.

\section{Conclusion}

The levels of glycogen and lactate that were examined in this study show that more favourable pork $L L$ muscle $\mathrm{pH}$, drip loss, and $\mathrm{L}^{\star} \mathrm{a}^{*} \mathrm{~b}^{\star}$ values are generally associated with lower concentrations of these metabolites. If glycogen was at least $35 \mu \mathrm{mol} / \mathrm{g}$ of muscle tissue, its further rise did not influence pork quality, which leads to the possibility of sorting carcasses prior to the onset of rigor mortis using its concentration as a criterion. Because the majority of muscle samples had adequate glycogen concentrations, lactate levels are also deemed to be a useful and valuable indicator of pork quality.

\section{Authors' Contributions}

AZ designed the study and analysed the data. KT prepared and revised the manuscript. HS, EK-N and KA edited the layout and content of the manuscript. All authors approved the final manuscript after critical revision.

\section{Conflict of Interest Declaration}

The authors declare that there is no conflict of interest between them and other people or organizations that could inappropriately bias the results.

\section{References}

Andersen, P.V., Veiseth-Kent, E. \& Wold, P.J., 2017. Analyzing pH-induced changes in a myofibril model system with vibrational and fluorescence spectroscopy. Meat Sci. 125, 1-9. Doi: 10.1016/j.meatsci.2016.11.005

Bergmeyer, H.U., 1974. Methods of enzymatic analysis. Academic Press, New York, USA.

Choe, J.H., Choi, Y.M., Lee, S.H., Shin, H.G., Ryu, Y.C., Hong, K.C. \& Kim, B.C., 2008. The relation between glycogen, lactate content and muscle fiber type composition, and their influence on postmortem glycolytic rate and pork quality. Meat Sci. 80, 355-362. Doi: 10.1016/j.meatsci.2007.12.019

Dalrymple, R.H. \& Hamm, R., 1973. A method for the extraction of glycogen and metabolites from a single muscle sample. J. Food Technol. 8, 439-444. Doi: 10.1111/j.1365-2621.1973.tb01730.x

Dokmanović, M., Baltić, M.Z., Durić, J., Ivanović, J., Popović, L., Todorović, M., Marković, R. \& Pantić, S., 2015. Correlations among stress parameters, meat and carcass quality parameters in pigs. Asian-Australas. J. Anim. Sci. 28, 3, 435-441. Doi: 10.5713/ajas.14.0322

England, E.M., Matarneh, S.K., Olivier, E.M., Apaoblaza, A., Scheffler, T.L., Shi, H. \& Gerrard D.E., 2016. Excess glycogen does not resolve high ultimate $\mathrm{pH}$ of oxidative muscle. Meat Sci. 114, 95-102. Doi: 10.1016/j.meatsci.2015.10.010

England, E.M., Matarneh, S.K., Scheffler, T.L., Wachet, C. \& Gerrard, D.E., 2014. pH inactivation of phosphofructokinase arrests postmortem glycolysis. Meat Sci. 98, 850-857. Doi: 10.1016/j.meatsci.2014.07.019

England, E.M., Matarneh, S.K., Scheffler, T.L., Wachet, C. \& Gerrard, D.E., 2015. Altered AMP deaminase activity may extend postmortem glycolysis. Meat Sci. 102, 8-14. Doi: 10.1016/j.meatsci.2014.11.009

Fischer, K., 2007. Drip loss in pork: Influencing factors and relation to further meat quality traits. J. Anim. Breed. Gen. 124, Suppl. 1, 12-18. https://doi.org/10.1111/j.1439-0388.2007.00682.x

Font-i-Furnols, M. \& Guerrero, L., 2014. Consumer preference, behavior and perception about meat and meat products: An overview. Meat Sci. 98, 361-371. Doi: 10.1016/j.meatsci.2014.06.025 
Fujii, J., Otsu, K., Zorzato, F., de Leon, S., Khanna, V.K., Weiler, J.E., O’Brien, P.J. \& MacLennan, D.H., 1991. Identification of a mutation in porcine ryanodine receptor associated with malignant hyperthermia. Science 253 , 448-450. DOI: $10.1126 /$ science.1862346

Hambrecht, E., Eissen, J.J., Newman, D.J., Smits, C.H.M., den Hartog, L.A. \& Verstegen, M.W.A., 2005. Negative effects of stress immediately before slaughter on pork quality are aggravated by suboptimal transport and lairage conditions J. Anim. Sci., 83, 440-448. DOI: 10.2527/2005.832440x

Hamm, R., 1977. Postmortem breakdown of ATP and glycogen in ground muscle: A review. Meat Sci. 1, 1, 15-39. Doi: 10.1016/0309-1740(77)90029-8

Henckel, P., Karlsson, A., Jensen, M.T., Oksbjerg, N. \& Petersen, J.S., 2002. Metabolic conditions in porcine Longissimus muscle immediately pre-slaughter and its influence on peri-and postmortem energy metabolism. Meat Sci. 62, 2, 145-155. DOI: 10.1016/s0309-1740(01)00239-x

Huff-Lonergan, E., Baas, T.J., Malek, M., Dekkers, J.C.M., Prusa, K. \& Rothschild, M.F., 2002. Correlations among selected pork quality traits. J. Anim. Sci. 80, 617-627. https://doi.org/10.2527/2002.803617x

Kawasaki, E.S., 1990. Sample preparation from blood cells and other fluids. In: M.A. Innis, D.H. Gelfamd, J.J. Sninsky \& T.J. White (eds). PCR protocols: A guide to methods and applications. Academic Press, London, UK, pp. 146152.

Knox, B.L., Van Laack, R.L.J.M. \& Davidson, P.M., 2008. Relationships between ultimate pH and microbial, chemical, and physical characteristics of vacuum-packaged pork loins. J. Food Sci. 73, 3, m104-m110. Doi: 10.1111/j.1750 3841.2008.00667.x

Koćwin-Podsiadła, M., Krzęcio, E. \& Przybylski, W., 2006. Pork quality and methods of its evaluation - a review. Pol. J. Food Nutr. Sci. 15/56, 3, 241-248.

Lebret, B., Prunier, A., Bonhomme, N., Foury, A., Morméde, P. \& Dourmad, J.Y., 2011. Physiological traits and meat quality of pigs as affected by genotype and housing system. Meat Sci. 88, 14-22. Doi: 10.1016/j.meatsci.2010.11.025

Lonergan, S.M., Huff-Lonergan, E., Rowe, L.J., Kuhlers, D.L. \& Jungst, S.B., 2001. Selection for lean growth efficiency in Duroc pigs influences pork quality. J. Anim. Sci. 79, 2075-2085. Doi: 10.2527/2001.7982075x

Monin, G. \& Sellier, P., 1985. Pork of low technological quality with a normal rate of muscle pH fall in the immediate postmortem period: The case of the Hampshire breed. Meat Sci. 13, 49-63. Doi: 10.1016/S0309-1740(85)80004-8

Nache, M., Jörg, J., Scheier, R., Schmidt, H. \& Hitzmann, B., 2016. Prediction of the pH as indicator of porcine meat quality using Raman spectroscopy and metaheuristics. Chem. Intell. Lab. Sys. 154, 45-51. https://doi.org/10.1016/j.chemolab.2016.03.011

Otto G., Knap P.W., Roehe R., Looft H., Cavero D. \& Kalm E., 2007. Different approaches of estimating economical values for drip loss as lognormally distributed trait. Livest. Sci. 112, 43-51. https://doi.org/10.1016/j.livsci.2007.01.155

Pearson, A.M. \& Young, R.B., 1989. Postmortem changes during conversion of muscle to meat. Muscle and Meat Biochemistry. Academic Press, San Diego, USA.

Pösö, A.R. \& Puolanne, E., 2005. Carbohydrate metabolism in meat animals. Meat Sci. 70, 3, 423-434. https://doi.org/10.1016/j.meatsci.2004.12.017

Prange, H., Jugrrt, L. \& Scharner, E., 1977. Untersuchungen zur Muskel fleischqualitätbeim Schwein. Arch. Exp. Vet. Med. Leipzig 31, 2, 235-248 (in German).

Rybarczyk, A., Moroch, R. \& Polasik, D., 2018. The effect of DanAvl Duroc and Pulawska boars in crossbred with DanAvl hybrid on meat quality of finishing pigs. Agr. Food Sci. 27, 159-16. Doi: 10.23986/afsci.70934

Ryu, Y.C. \& Kim, B.C., 2005. The relationship between muscle fiber characteristics, postmortem metabolic rate, and meat quality of pig longissimus dorsi muscle. Meat Sci. 71, 351-357. Doi: 10.1016/j.meatsci.2005.04.015

Ryu, Y.C., Choi, Y.M. \& Kim, B.C., 2005. Variations in metabolite contents and protein denaturation of the longissimus dorsi muscle in various porcine quality classifications and metabolic rates. Meat Sci. 71, 522-529. Doi: 10.1016/j.meatsci.2005.04.034

Schäfer, A., Rosenvold, K., Purslow, P., Andersen, H. \& Henckel P., 2002. Physiological and structural events post mortem of importance for drip loss in pork. Meat Sci. 61, 355-366. https://doi.org/10.1016/S0309-1740(01)00205-4

Scheffler, T.L., Scheffler, J.M., Kasten, S.C., Sosnicki, A.A. \& Gerrard, D.E., 2013. High glycolytic potential does not predict low ultimate $\mathrm{pH}$ in pork. Meat Sci. 95, 85-91. https://doi.org/10.1016/j.meatsci.2013.04.013

Scheier, R., Scheeder, M. \& Schmidt, H., 2015. Prediction of pork quality at the slaughter line using a portable Raman device. Meat Sci. 103, 96-103. Doi: 10.1016/j.meatsci.2015.01.009

Shapiro, S.S. \& Wilk, M.S., 1965. An analysis of variance test for normality (complete samples). Biometrika 52, 591-611; Doi: $10.2307 / 2333709$

Tarczyński, K., Sieczkowska, H., Zybert, A., Krzęcio-Nieczyporuk, E. \& Antosik, K., 2018. pH measured 24 hours post mortem should not be regarded as ultimate $\mathrm{pH}$ in pork meat quality evaluation. S. Afr. J. Anim. Sci. 48, 6, 10091016. http://dx.doi.org/10.4314/sajas.v48i6.2

Van Laack, R.L.J.M. \& Kauffmann, R.G., 1999. Glycolytic potential of red, soft, exudative pork Longissimus muscle. J. Anim. Sci. 77, 2971-2973. https://doi.org/10.2527/1999.77112971x

Van Laack, R.L.J.M., 2000. Determinants of Ultimate pH of meat and poultry. Proc. 53rd Ann. Recip. Meat Conf., Ohio. pp. 74-75.

Verbeke, W., De Smet, S., Vackier, I., Van Oeckel, M.J., Warnants, N. \& Van Kenhove, P., 2005. Role of intrinsic search cues in the formation of consumer preferences and choice for pork chops. Meat Sci. 69, 343-354. https://doi.org/10.1016/j.meatsci.2004.08.005 
Wang, W., Peng, Y., Sun, H., Zheng, X. \& Wei, W., 2018. Real-time inspection of pork quality attributes using dual-band spectroscopy. J. Food. Eng. 237, 103-109. https://doi.org/10.1016/j.jfoodeng.2018.05.022

Zhang, J., Chai, J., Luo, Z., He, H., Chen, L., Liu, X. \& Hou, Q., 2018. Meat and nutritional quality comparison of purebred and crossbred pigs. Anim. Sci. J. 89, 202-210. https://doi.org/10.1111/asj.12878

Zybert, A., Protasiuk, E., Antosik, K., Sieczkowska, H, Krzęcio-Nieczyporuk, E., Adamczyk, G. \& Koćwin-Podsiadła, M., 2014. Variations in $\mathrm{pH}$ decline measured from $45 \mathrm{~min}$ to $48 \mathrm{~h}$ postmortem as related to meat quality of $(\mathrm{L} \times \mathrm{Y}) \times \mathrm{H}$ fatteners. Ann. Anim. Sci. 14, 2, 461-469. https://doi.org/10.2478/aoas-2014-0018

Zybert, A., Tarczyński, K., \& Sieczkowska, H., 2019. Meta-analysis of the effect of chilling on selected attributes of fresh pork. J Food Process Preserv. 43, e14061. https://doi.org/10.1111/jfpp.14061

Zybert, A., Tarczyński, K., Sieczkowska, H. \& Koćwin-Podsiadła, M., 2015. Glycolytic and energetic resources as the determinants of meat quality of Duroc fatteners. J. Cent. Eur. Agr. 16, 1, 177-187. Doi: 10.5513/JCEA01/16.1.1560 